\title{
TEACHING UKRAINIAN AS A NON-NATIVE LANGUAGE TO NATIONAL MINORITIES IN UKRAINE: CHALLENGES FOR EVIDENCE-BASED EDUCATIONAL POLICIES
}

\author{
Oksana Zabolotna ${ }^{1}$ \\ (Corresponding author: oxana.zabolotna@gmail.com) \\ Svitlana Shchudlo ${ }^{2}$, Tetiana Medina ${ }^{3}$, Ielyzaveta Panchenko ${ }^{4}$, Dmytro Kozlov ${ }^{5}$ \\ ${ }^{1,4}$ Pavlo Tychyna Uman State Pedagogical University, Uman, Ukraine \\ ${ }^{2}$ Drohobych Ivan Franko State Pedagogical University, Drohobych, Ukraine \\ ${ }^{3}$ Yuriy Fedkovych Chernivtsi National University, Chernivtsi, Ukraine \\ ${ }^{5}$ A.S. Makarenko Sumy State Pedagogical University, Sumy, Ukraine
}

\begin{abstract}
Underachievement among national minority group students in places of their compact residence in Ukraine makes them vulnerable to educational failure. This problem is noticeable in Chernivtsi Region of Ukraine where the multicultural character causes peculiar behaviour in politics, migration, economic and cultural activities as well as in educational strategies. Owing to the fact that in some districts (Hertsa and Novoselica) the Ukrainian Language is not the mother tongue for most residents who are ethnical Romanians and Moldavians, about $60 \%$ students fail in Independent External Testing after secondary school. This issue was taken into account in Article 7 of Ukrainian Law on Education (2017) which presupposed gradual significant growth in school subjects with Ukrainian as the language of instruction. The issue raised the research question: What approaches can be applied to teaching Ukrainian as a non-native language to national minorities in sites of their compact residence (where more than $80 \%$ of the population speak Romanian in their everyday life)? This actualised the need for formulating evidence-based language policies in Ukraine. With the purpose of answering the need, Ukrainian Educational Research Association designed and carried out a public perception survey using in-depth interviews with high-school students and their parents, school teachers, local and regional policy-makers in education, local authorities, and national cultural societies. Based on the research, the authors give recommendations on approaches which should be used in design of curriculum and syllabus of Ukrainian as a non-native language. The authors emphasise the importance of the gradual introduction of the Ukrainian language starting from learning it as a foreign language at initial stages, with further switching to second language teaching strategies, and leading to bilingual education.
\end{abstract}

Keywords: national minority students; evidence-based language policies; Ukrainian as a non-native language.

\section{Introduction}

In recent years, language policies in Ukraine as a democratic country have been actively criticised as not satisfying national minorities' needs. The issue was even more urgently addressed after the analysis of External Independent Testing results demonstrating national minority group students' considerable underachievement which was especially noticeable in places of their compact residence in Ukraine. This situation makes them vulnerable to educational failure. This problem is noticeable in Chernivtsi Region of Ukraine where multiculturalism is the point of departure as students who speak Ukrainian and those who speak Romanian share the same school class with the percentage of Romanian speaking students varying substantively depending on whether it is an urban or a rural area. There is a particular density of Romanian and Moldavian population in Hertsa, Novoselica, Chernivtsi as sites of national minorities' compact residence, which should be taken into account in defining educational strategies. Owing to the fact that in some districts (Hertsa and Novoselica) the Ukrainian Language is not the mother tongue for most residents who are ethnical Romanians and Moldavians, about $60 \%$ students fail in Independent External Testing after secondary school. This issue was taken into account in Article 7 of Ukrainian Law on Education (2017) which presupposed a gradual significant raise of proportion of school subjects taught in Ukrainian. The Article underwent an active protest on the part of Romanian minority groups who demanded that Article 7 should be changed as contradicting human rights. The Ukrainian Foreign Ministry sent the education law for examination to the Venice Commission which did not support accusations of narrowing the rights of national minorities in the article on the language of instruction in Ukraine's law on education. So, the research question is: what approaches should be used in design of the curriculum and syllabus of Ukrainian as a nonnative language?

The issue of language education policies in multilingual settings used to be presented in terms of traditional monolingual approaches which have been recently revisited (Gramling, 2016). As Gogolin (1997) put it a few decades ago, 'It is founded on the basic and deep-seated conviction that monolingualism in a society, and particularly in schools, is the one and only normality, forever and always valid: the characteristic of a nation'(p. 46). She showed Germany as an example of a country where it is "reflected in educational 
norms, structural precedents, and the content of teaching ... and establishing monolingualism in the official national language is an imperative in a teacher's professional ethos" (Gogolin, 1997, p.46).

Other authors (Baker \& Jones, 1998; Garcia, 2011; Nikula, 2016; Cahyani, de Courcy, \& Barnett, 2018; Sánchez, García, \& Solorza, 2018; Creese, \& Blackledge, 2015; García-Mateus \& Palmer, 2017) approach the issue at an angle of bilingual education explaining that it is "a simple label for a complex phenomenon" (Baker \& Jones, 1998, p. 494), that might be understood as "the education of those who are studying additional languages. Some students who learn additional languages are already speakers of the majority language(s) used in their society, while sometimes they are ..., members of minoritised groups... learning a different language, the dominant language, in school" (Garcia, 2011, p. 12). The authors state that bilingual education and traditional teaching a second or a foreign language have a noticeable difference as "For the most part, these traditional second or foreign-language programmes teach the language as a subject, whereas bilingual education programmes use the language as a medium of instruction (Garcia, 2011, p. 13). In this context CLIL (Content and Language Integrated Learning) often appears as "a term used especially in Europe for forms of bilingual education where an additional language ... is used as the language of instruction in nonlanguage school subjects" (Nikula, 2016, p. 14). For distinguishing between bilingual and foreign / second language education in terms of their goals, use and pedagogical implications see table 1 .

\section{Differences between Bilingual Education and Language Education (Garcia, 2011)}

\begin{tabular}{|l|l|l|}
\hline & Bilingual Education & Foreign or Second-Language Education \\
\hline Overarching Goal & Educate meaningfully & Competence in an additional language \\
\hline Academic Goal & $\begin{array}{l}\text { Educate bilingually and be } \\
\text { able to function across cultures }\end{array}$ & $\begin{array}{l}\text { Learn an additional language and } \\
\text { become familiar with an additional } \\
\text { culture }\end{array}$ \\
\hline Language Use & $\begin{array}{l}\text { Languages used as media of } \\
\text { instruction }\end{array}$ & Additional language taught as a subject \\
\hline $\begin{array}{l}\text { Instructional Use of } \\
\text { Language }\end{array}$ & $\begin{array}{l}\text { Uses some form of two or } \\
\text { more languages }\end{array}$ & Uses target language mostly \\
\hline Pedagogical Emphasis & $\begin{array}{l}\text { Integration of language and } \\
\text { content }\end{array}$ & Explicit language instruction \\
\hline
\end{tabular}

All the mentioned above brings about the necessity of defining the status of Ukrainian and Romanian in the research context. As it is explained in the Eurydice report on Key Data on Teaching Languages at School in Europe (Baïdak, Balcon, \& Motiejunaite, 2017), "the description is based on an education-related definition, unrelated to the political status of a language. Thus certain languages regarded as regional or minority languages from a political perspective may be included in the curriculum as foreign languages...Elsewhere, the term 'first language' may be used to describe the language of schooling, with other languages being referred to as 'second' or 'third' languages - this is often the case in countries with more than one state language" (Baïdak at al., 2017, p. 4).

\section{Method}

\section{General Background of Research}

National minority students' vulnerability to educational failure, on the one hand, and language-based pressure on the part of neighbouring countries, on the other hand, actualised the need for formulating evidence-based language policies in Ukraine. With the purpose of answering the need, Ukrainian Educational Research Association carried out the grant project "Facilitating an Intercultural Dialogue about National Minorities' Learning the Ukrainian Language in Chernivtsi Region” (№ PФР-38-2018 dated 02.05.2018) (02.05.2018 - 31.07.2018) as part of "Reforms to the Regions Project" realised by the Institute of Economic Research and Political Consultations and the European Truth newspaper (funded by European Commission and International Renaissance Foundation). Within the Project, the Ukrainian Educational Research Association (UERA) team analysed the historical and cultural background of the current languagerelated situation in Chernivtsi Region (Hertsa and Novoselica Districts and the City of Chernivtsi as sites of compact national minorities' residence).

The purpose of the research was to contribute to the promotion of Ukrainian language as state language among national minorities in Chernivtsi Region, support the Ministry of Education and Science of Ukraine in raising awareness and positive attitudes towards the school reform and its benefits among national minorities 
in the target regions in Chernivtsi Region in particular, help to facilitate interactive communication, create an active flow of information between all relevant stakeholders and media, and maintain transparency of cooperation and results.

The purpose-related objectives were:

- to design and carry out a public perception survey using in-depth interviews with high-school students and their parents, school teachers, local and regional policy-makers in education, local authorities, and national cultural societies;

- to deliver evidence-based analysis with the UERA recommendations to the Ukrainian Ministry of Education and Science on approaches which should be used in the design of curriculum and syllabus of Ukrainian as a non-native language that would not contradict the state interests and preserving the minorities' national identity.

\section{Participants}

The authors draw their conclusions from qualitative research based on 70 in-depth interviews with the main stakeholders. The statistical population is the project target groups, namely school principals, school administration team, high school students, high school students' parents, university students, national cultural NGO representatives, political parties, and local authority representatives. The sample units are the mentioned above categories who live/work in 2 districts of Chernivtsi Region where Romanian population compactly reside (Hertsa and Novoselica), as well as the city of Chernivtsi. A sample of a target group is broken down by mother language and the region of residence.

Table 2

The participants' distribution by place of residence

\begin{tabular}{|l|c|c|c|c|}
\hline \multicolumn{1}{|c|}{ Interviewed group } & \multicolumn{3}{c|}{ Place of residence } \\
\cline { 2 - 5 } & Chernivtsi & Hertsa & $\begin{array}{c}\text { Novose- } \\
\text { lica }\end{array}$ & Total \\
\hline Local authorities & 5 & 3 & 3 & 11 \\
\hline School authorities & 6 & 4 & 3 & 13 \\
\hline Teachers & 5 & 4 & 3 & 12 \\
\hline Parents & 2 & 3 & 2 & 6 \\
\hline High-school students & 5 & 3 & 2 & 10 \\
\hline University students & 6 & - & - & 6 \\
\hline National cultural societies & 3 & 1 & 1 & 5 \\
\hline Employers & 2 & & & 2 \\
\hline Political parties' representatives & 2 & 1 & 1 & 4 \\
\hline & 36 & 19 & 15 & 70 \\
\hline
\end{tabular}

\section{Instrument and Procedures}

The Institute of Economic Research and Political Consultations provided the research team with the interview guide containing the questions connected with the quality of teaching Ukrainian at schools, the participants' attitudes towards language policies, and Article 7 (Law of Education) in particular. All the indepth interviews were recorded and their transcripts are available. The prevalent method was content analysis. The research was carried out with all the ethical norms and the respondents were coded.

\section{Results}

\section{Factors influencing the national minority students' competence in the Ukrainian Language}

The in-depth interviews provided material for defining some factors influencing the national minority students' competence in the Ukrainian Language. As proved by Independent External Testing 2018 analysis, the students of schools with Romanian as the language of instruction demonstrated considerably lower achievement levels in the Ukrainian language.

The reasons for underachievement and the number of respondents supporting them are provided in the table (see Table 3) 
Table 3

Reasons for underachievement in the Ukrainian language as defined by the respondents

\begin{tabular}{|c|c|c|c|c|c|c|}
\hline & 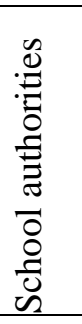 & 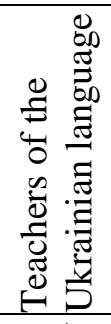 & 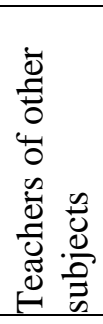 & 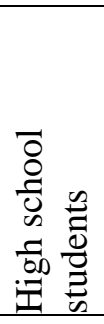 & 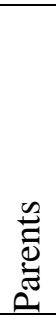 & $\stackrel{\widetilde{\pi}}{0}$ \\
\hline $\begin{array}{l}\text { Difficulty in speaking Ukrainian and Romanian } \\
\text { equally well because of the language interference }\end{array}$ & 2 & 1 & 1 & 2 & & 4 \\
\hline $\begin{array}{l}\text { Different number of hours allocated in different } \\
\text { schools to the subjects in which the students take } \\
\text { Independent External Testing }\end{array}$ & 1 & & & & & 1 \\
\hline Students contingent & 3 & & & & & 3 \\
\hline Lack of good teachers & 2 & & 1 & 1 & & 5 \\
\hline Lack of students' motivation & 5 & 2 & 2 & 2 & 2 & 13 \\
\hline $\begin{array}{l}\text { Compulsory Independent External Assessment in the } \\
\text { Ukrainian language }\end{array}$ & 1 & & 2 & & & 4 \\
\hline Student emigration plans & 3 & & 4 & 3 & 4 & 14 \\
\hline Lack of interest on the part of the family & 3 & & & & & 3 \\
\hline $\begin{array}{l}\text { Lack of teachers' motivation to deliver their subjects } \\
\text { in Ukrainian }\end{array}$ & 1 & & & & & 1 \\
\hline $\begin{array}{l}\text { Inconsistencies in Independent External Assessment } \\
\text { tasks and school subject syllabi }\end{array}$ & 1 & & & 2 & 2 & 5 \\
\hline
\end{tabular}

As seen from the table the most influential reasons for the students' underachievement in the Ukrainian Language are: their emigration plans (14 respondents), lack of students' motivation (13 respondents), Inconsistencies in Independent External Assessment tasks and school subject syllabi (5 respondents), and lack of good teachers (5 respondents).

\section{Ways of solving the national minority students' underachievement problems}

In the in-depth interview, the participants shared their vision of solving the problem of the students' underachievement in the Ukrainian Language. The ways offered by them are listed in the table (see Table 4).

Ways of solving the national minority students' underachievement problems offered by the

Table 4 respondents

Ways of solving minority students' underachievement problems offered by the respondents

Self-education and private tutoring

Students' psychological support Increasing the number of hours for learning Ukrainian Vocational education after Grade 9 Ukrainian as the language of instruction from Grade 1 Extra-curricular events in Ukrainian Using more Ukrainian in the Internet and media

\begin{tabular}{|c|c|c|c|c|c|}
\hline 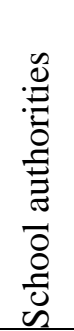 & 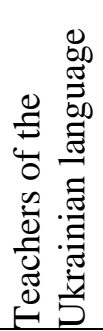 & 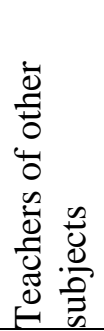 & 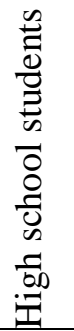 & 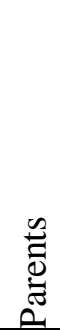 & $\stackrel{\text { त्ञँ }}{0}$ \\
\hline 2 & 1 & & & & 3 \\
\hline 1 & & & & & 1 \\
\hline 2 & 2 & 1 & 1 & & 4 \\
\hline 2 & & & & & 2 \\
\hline 2 & & 1 & 1 & & 4 \\
\hline 1 & 2 & 1 & 2 & 1 & 7 \\
\hline 1 & 2 & 3 & & & 6 \\
\hline
\end{tabular}

(to be continued) 
Table 4

Ways of solving the national minority students' underachievement problems offered by the respondents (continued)

\begin{tabular}{|c|c|c|c|c|c|c|}
\hline & & & & & & \\
\hline $\begin{array}{l}\text { Ways of solving minority students' underachievement } \\
\text { problems offered by the respondents }\end{array}$ & 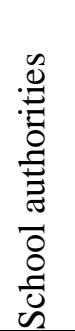 & 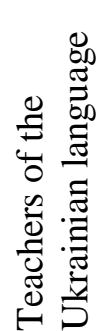 & 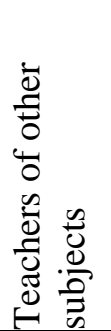 & 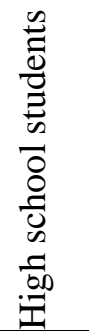 & 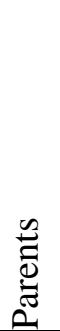 & $\stackrel{\widetilde{T}}{0}$ \\
\hline $\begin{array}{l}\text { Specially designed Ukrainian course for teachers and } \\
\text { students }\end{array}$ & 1 & 1 & 2 & & & 4 \\
\hline Special teacher training for national minority schools & 1 & 1 & & & & 2 \\
\hline $\begin{array}{l}\text { The gradual shift to Ukrainian as the language of } \\
\text { instruction }\end{array}$ & 1 & 1 & 1 & & & 2 \\
\hline $\begin{array}{l}\text { Increasing salary for national minority school teachers } \\
\text { who deliver their subjects in Ukrainian }\end{array}$ & 2 & & & & & 2 \\
\hline Sunday school development & & 1 & & & & 1 \\
\hline Selecting the course books by the teacher & & 1 & & & & 1 \\
\hline Creating educational centres for high school students & & & 1 & & & 1 \\
\hline Bilingual education & & & 2 & & 1 & 3 \\
\hline $\begin{array}{l}\text { Improving the Ukrainian language and literature } \\
\text { curriculum }\end{array}$ & & & & 1 & 2 & 3 \\
\hline
\end{tabular}

Thus, the authors can rate the top three ways offered by the interview participants:

- Extra-curricular events in the Ukrainian Language

- Using more Ukrainian in the Internet and media

- Increasing the number of hours for learning Ukrainian

Two of the mentioned above positions are not school-based, thus in offering the strategy, the authors would rely on the status the students attach to Ukrainian and Romanian. That is which of them they consider their mother tongue, first language, second language, foreign language, dominant language, minority language, and an official language. It should be noted though that there is considerable overlap between these groups:

Mother tongue. A general term for the language of the childhood home learned "at one's mother's knee", often used synonymously with native language. Although the implication is usually clear, there is no necessary connection between a child's use of language and the language of its mother: some children learn the language of a nurse or ayah first; a mother may talk to her child in a language not originally her own; the mother may be dead (Mother Tongue, n.d.).

First language. The language in which learners are competent when starting a new language. An L1 may or may not be a learner's mother tongue, because a chronologically first language may not be the functionally first language of adulthood (First Language, n.d.).

Second language. Another language that is being learned or has been learned to an adequate level. Under certain conditions, such as migration, an original L2 may become a person's L1 or only language. (The First Language, 2019)

Foreign language. A language not commonly used in the students country of residence (Baker and Jones, 1998).

Dominant language. May be used by the ruling elite in education, administration, the mass media, the judicial system and other prestigious functions, and will reflect the prestige and status of those functions. It will also be an expression of the culture and ethnic identity of the controlling power. Entry into the dominant group and access to power and economic success may depend on mastery of the dominant language. The dominant language is regarded by both members of the dominant and the subordinate groups as valuable, prestigious, correct and superior (Baker and Jones, 1998).

Minority language. If the speakers of a non-standardised language are a minority group within a country, they may wish to gain power, status and a measure of cultural or political autonomy for the group. As part of their goal they may try to elevate the status and increase the use of the minority language, as an 
important marker of the group's identity and distinctive character, and so that it may be used in education, administration and other prestigious functions (Baker and Jones, 1998).

Official language. It is generally the language used in government, administration and education. Many countries have a legally designated official language. In countries where the overwhelming majority of the population speak one language, the official language may never have been ratified by law (Baker and Jones, 1998)

The above-mentioned division can be used for defining the key status-dependent characteristics for the languages in terms of their usage and functions (see table 5)

Table 5

The key status-dependent characteristics for the languages

\begin{tabular}{|c|c|c|c|c|c|c|}
\hline $\begin{array}{c}\text { Characte- } \\
\text { ristics }\end{array}$ & $\begin{array}{l}\text { Mother } \\
\text { tongue }\end{array}$ & First language & $\begin{array}{c}\text { Second } \\
\text { language }\end{array}$ & $\begin{array}{l}\text { Foreign } \\
\text { language }\end{array}$ & $\begin{array}{l}\text { Minority } \\
\text { language }\end{array}$ & $\begin{array}{l}\text { Dominant } \\
\text { language }\end{array}$ \\
\hline Usage & $\begin{array}{l}\text { in the } \\
\text { family }\end{array}$ & $\begin{array}{l}\text { in the family } \\
\text { and in } \\
\text { communication } \\
\text { with peers }\end{array}$ & $\begin{array}{l}\text { in education } \\
\text { and in } \\
\text { communication } \\
\text { with peers }\end{array}$ & $\begin{array}{c}\text { in } \\
\text { education }\end{array}$ & $\begin{array}{l}\text { in the } \\
\text { minority } \\
\text { group }\end{array}$ & $\begin{array}{c}\text { in } \\
\text { government, } \\
\text { administration } \\
\text { and education }\end{array}$ \\
\hline Functions & $\begin{array}{l}\text { a marker of } \\
\text { belonging } \\
\text { to a family }\end{array}$ & $\begin{array}{l}\text { a marker of } \\
\text { belonging to a } \\
\text { family or a } \\
\text { peer group }\end{array}$ & $\begin{array}{c}\text { a marker of } \\
\text { belonging to a } \\
\text { peer group }\end{array}$ & $\begin{array}{l}\text { a marker of } \\
\text { belonging } \\
\text { to a peer } \\
\text { group in an } \\
\text { educational } \\
\text { institution }\end{array}$ & $\begin{array}{c}\text { a marker of } \\
\text { belonging to } \\
\text { a minority } \\
\text { group }\end{array}$ & $\begin{array}{l}\text { a marker of } \\
\text { belonging to a } \\
\text { majority } \\
\text { group }\end{array}$ \\
\hline
\end{tabular}

These characteristics can help to trace the national minority representatives' (high school students, parents and national cultural society members) attitudes towards Ukrainian and Romanian which will serve the starting point for defining the strategy for teaching Ukrainian as a non-native language to national minorities in Ukraine.

For tracing the attitudes, the authors applied a content analysis of the in-depth interview transcripts where the descriptors and connotations applied to the languages (Ukrainian and Romanian) were matched to their key status-dependent characteristics. The authors found out that those were directly connected to the respondents' place of residence. The information is based on the majority of the respondents providing evidence of their attitude to the language through descriptors and connotations in the interview transcripts. It shows that the principal difference lies in perception Ukrainian as the second language by the respondents residing in Chernivtsi, and as a foreign language by the respondents from the sites of national minority compact residence. This urges the need for applying two different approaches to teaching Ukrainian to these categories.

\section{Discussion}

The diversity of language is an important aspect for all the children in their daily language experience, be they themselves mono- or multilingual. Independent of whether or not the school pays attention to it, diversity of language is a common element of the socialisation of all children in a society ... Schools should, therefore, take this into account when they set teaching standards and goals (Gogolin, 1997, p. 46). In the case of Chernivtsi Region in Ukraine, a balance should be achieved between Ukrainian as the dominant and official language and Romanian which is for national minority representatives is the only way to preserve their identity. "Looking at languages as being in conflict, and one language only being able to thrive at the expense of another, is not a very helpful or productive perspective in this respect. What is needed is a radical shift from an either-or to both-and logic in thinking about languages and education" (Weber, 2014, p. 4).

The research shows that revisiting the traditional monolingual approaches (Gramling, 2016) and applying them through monolingualism in schools (Gogolin, 1997, p. 46) is not the case in Chernivtsi Region. In spite of the fact that it gives a characteristic of a nation and conveys national norms, teaching cannot be delivered solely in the official language in the sites of national minorities' compact residence throughout school education. Historically, national minorities residing there are not immigrants who would easily like to merge with the dominant culture. On the contrary, they feel integrated but at the same time are trying to preserve their Romanian identity, and communities "firmly believe that children's cultures and languages are assets which could be used in service to academic success in school" (Escamilla, 2018, p. 369). 
Thus, gradual introduction of the Ukrainian language starting from learning it as a foreign language at initial stages, with further switching to second language teaching strategies, and leading to bilingual education which is not just the sum of two languages but takes into "account ... how languages are used in society, or ... real bilingual and multilingual practices" (Garcia, 2011) as well as the use of Content and Language Integrated Learning (CLIL). This definitely implies numerous challenges that should be dealt with, namely, teachers' code-switching in bilingual classrooms (Cahyani et al., 2018), reframing language allocation policy (Sánchez et al., 2018); the relationship between language and identities in contexts where communication is mobile and complex (Creese, \& Blackledge, 2015), forming positive identities in bilingual education (García-Mateus \& Palmer, 2017) etc.

The authors have developed recommendations for policy-makers taking into account the importance of reaching the balance between the necessity to speak Ukrainian as the state language and national minorities' striving to preserve their identity. The recommendations are focused on state, university, regional, local, and school levels. At the state level, they suggest that school students with the mother tongue other than Ukrainian should be considered students with special needs. If accepted, this provides the schools with the right to employ teacher assistants helpful in creating a bilingual learning environment. The recommendations for universities deal with the training of teachers for work in bilingual settings, which can be realised by introducing courses and training programmes on teaching in bilingual settings at BA level; the training programme for teacher assistants in bilingual settings; in-service courses for teachers within their professional development courses.

The research has shown that the key problem does not lie in teaching and learning Ukrainian as a school subject. As the experts state the main focus should be on teaching Ukrainian as the Language for Special Purposes, and the approaches to this are quite different from teaching Ukrainian for General Purposes, which may raise the teachers' interest as they see the direct relation to their subject. Nevertheless, the authors realise the challenge of teaching Ukrainian separately to teachers of different school subjects, and the lack of teachers of Ukrainian ready to do it. Thus relevant modules should be introduced into pre-service and inservice training of teachers of Ukrainian.

At the local level, the authors suggest that teacher training for work in bilingual settings should take place in resource centres in united rural communities in the sites of compact national minority residence. They also stress that the mother tongue should also be paid proper attention to as it helps to preserve national identity.

\section{Conclusion}

The research has revealed a number of challenges for evidence-based educational policies concerning teaching Ukrainian as a non-native language to national minorities in Ukraine. On the one hand, they deal with political pressure on the part of neighbouring countries and national minorities urgent need to preserve their identity through their mother tongue which is under threat as it seems to them. On the other hand, Ukraine sees the Ukrainian language as an issue of the highest importance as it helps to preserve the unity of the country, convey values and traditions. Thus only a balanced language policy may meet the needs of both parties. It should influence educational standards and syllabus in a way that does not neglect human rights.

\section{Acknowledgements}

The article is based on the research carried out by the Ukrainian Educational Research Association within the grant project "Facilitating an Intercultural Dialogue about National Minorities' Learning the Ukrainian Language in Chernivtsi Region” (№ РФР-38-2018 dated 02.05.2018) (02.05.2018 - 31.07.2018) as part of "Reforms to the Regions Project" realised by the Institute of Economic Research and Political Consultations and the European Truth newspaper (funded by European Commission and International Renaissance Foundation). The authors are grateful to the respondents for their assistance.

\section{References:}

Baïdak, N., Balcon, M.-P., \& Motiejunaite, A. (2017). Eurydice Brief Key Data on Teaching Languages at School in Europe. Education, Audiovisual and Culture Executive Agency. Luxemburg: Publication Office of the European Union.

Baker, C. \& Jones, S. (1998). Encyclopedia of Bilingualism and Bilingual Education. Bristol, UK: Multilingual Matters

Cahyani, H., de Courcy, M. \& Barnett, J. (2018). Teachers' code-switching in bilingual classrooms: exploring pedagogical and sociocultural functions. International Journal of Bilingual Education and Bilingualism,21 (4), 465-479. https://doi.org/10.1080/13670050.2016.1189509

Creese, A., \& Blackledge, A. (2015). Translanguaging and identity in educational settings. Annual Review of Applied Linguistics, 35, 20-35. https://doi.org/10.1017/S0267190514000233

Escamilla, K. (2018). Growing up with the Bilingual Education Act: One educator's journey. Bilingual Research Journal, 41 (4), 369-387. https://doi.org/10.1080/15235882.2018.1529641 
First Language (n.d.). Concise Oxford Companion to the English Language. Retrieved January 20, 2019 from https://www.encyclopedia.com/humanities/encyclopedias-almanacs-transcripts-and-maps/first-language

Garcia, O (2011). Bilingual Education in the 21st Century: A Global Perspective. John Wiley \& Sons

García-Mateus, S. \& Palmer, D. (2017). Translanguaging Pedagogies for Positive Identities in Two-Way Dual Language Bilingual Education. Journal of Language, Identity \& Education, 16 (4), 245-255. https://doi.org/10.1080/15348458.2017.1329016

Gogolin, I. (1997).The "Monolingual Habitus" As the common feature in teaching in the language of the majority in different countries. Per Linguam, 13 (2) 38-49. Retrieved January 20, 2019 from http://perlinguam.journals.ac.za/pub/article/viewFile/187/298

Gramling, D. (2016). The Invention of Monolingualism. USA: Bloomsbury Publishing.

Mother Tongue (n.d.). Concise Oxford Companion to the English Language. Retrieved January 20, 2019 from https://www.encyclopedia.com/humanities/encyclopedias-almanacs-transcripts-and-maps/mother-tongue

Nikula, T. (2016). CLIL: A European Approach to Bilingual Education. In Van Deusen-Scholl N., May S. (eds.), Second and Foreign Language Education. Encyclopedia of Language and Education (3rd ed.). Cham: Springer.

Sánchez, M. T., García, O. \& Solorza, C. (2018). Reframing language allocation policy in dual language bilingual education. Bilingual Research Journal, 41(1), 37-51. https://doi.org/10.1080/15235882.2017.1405098

Weber, J.-J. (2014). Flexible Multilingual Education: Putting Children's Needs First. Bristol, UK: Multilingual Matters. 